logos_i_ethos_2017_1_(44), s. 7-31

DOI: http://dx.doi.org/10.15633/lie.2119

Marcin Subczak

Uniwersytet Rzeszowski

\title{
Antyczna tradycja filozoficznych sposobów życia jako wzorzec dla współczesności
}

Tak sformułowany tytuł artykułu sugeruje przynajmniej trzy tezy. Pierwsza $\mathrm{z}$ nich odnajduje $\mathrm{w}$ starożytności filozofię rozumianą jako sposób życia. Druga przyjmuje istnienie „współczesności”, której

Marcin Subczak, mgr - asystent w Zakładzie Historii Filozofii na Wydziale Socjologiczno-Historycznym Uniwersytetu Rzeszowskiego. Zainteresowania: historia filozofii starożytnej, historia filozofii średniowiecznej, antropologia, metafizyka, kultura antyczna i średniowieczna.

pewien jednolity charakter daje się w wyraźny sposób zidentyfikować i opisać. Wreszcie trzecia z tez - kluczowa, a jednocześnie najbardziej kontrowersyjna - zakłada istnienie możliwej relacji między antycznymi modelami filozoficznego życia a odpowiednio definiowaną „współczesnością”. Krytyka i kontrowersje dotyczące trzeciej z wymienionych tez wiążą się z zarzutem anachronizmu, jaki może się pojawić się wobec faktu zestawienia określonego rozumienia filozofii antycznej ze współczesnością, i to dodatkowo jeszcze w „modelowo-wzorczej” relacji. Próba konfrontacji filozofii antycznej pojmowanej jako sposób życia - z pewnym obrazem współczesności jest jednak celowa. Zamiarem niniejszej pracy jest bowiem przeanalizowanie możliwych zależności między tak właśnie rozumianą filozofią a współczesnymi wzorcami osobowymi. Dlatego też w pierwszej jej części przedstawię szkic antycznej filozofii rozumianej właśnie jako „sposób życia”, następnie postaram się zdefiniować współczesność w jej napięciu między nowoczesnością a ponowoczesnością, aby wreszcie zapytać o jakąkolwiek możliwość usytuowania tak rozumianej filozofii starożytnej w jej „wzorczej” zależności względem „współczesności”. W artykule tym nie będę jednak wskazywał żadnego konkretnego modelu antycznego 
sposobu życia, który miałby zostać współcześnie realizowany. Wyeksponuję raczej te aspekty ludzkiej kondycji, a zarazem te strukturalne cechy jakiegokolwiek modelu życia traktowanego w ogólności, które odnajdywane we współczesności, pozwalałyby mówić o ewentualnej aktualności filozoficznej egzystencji.

\section{Filozofia jako sposób życia}

Filozofia antyczna jest takim wytworem ludzkiego ducha, który mimo wielowiekowego dystansu - ciągle okazuje się być podatny na różnorakie interpretacje ${ }^{1}$. Nie mam tutaj na myśli doktrynalnych sporów między badaczami filozofii konkretnych przedstawicieli antyku, ale wskazuję raczej na istnienie rozbieżności w kwestiach bardziej zasadniczych, takich jak samo rozumienie istoty filozofii starożytnej, pojmowanie specyfiki filozofowania i charakteru bycia filozofem. Spójny obraz filozofii antycznej (na przykład jako ewoluującej problematyki zasad - archai ${ }^{2}$, gr. ảpxaí) może ulec zachwianiu wówczas, gdy zaakceptujemy fakt, że przynajmniej od czasów Sokratesa ${ }^{3}$ - sposób życia był tak samo ważny, jak teoretyczny dyskurs ${ }^{4}$. Dlatego też filozofia może być traktowana jako

1 Przykładem wspomnianych rozbieżności interpretacyjnych są te, które odnoszą się do myślicieli okresu przedsokratejskiego. Wątpliwości dotyczą bowiem tego, czy należy określić ich mianem „fizyków” czy raczej „teologów”. Jak zauważa Krzysztof Narecki, John Burnet i Theodor Gomperz zapoczątkowali pozytywistyczną tendencję postrzegania „presokratyków” jako empirystów i naukowców. Odmiennego zdania są James Adam i Werner Jaeger, którzy akcentują metafizyczny i teologiczny charakter myśli pierwszych filozofów greckich. Zob. K. Narecki, LOGOS we wczesnej myśli greckiej, Lublin 1999, s. 54-59; W. Jaeger, Teologia wczesnych filozofów greckich, przeł. J. Wocial, Kraków 2007, passim.

2 Zob. J. Gajda, Teorie wartości w filozofii przedplatońskiej, Wrocław 1992, passim; J. Gajda-Krynicka, Filozofia przedplatońska, Warszawa 2007, passim.

3 Zob. P. Paczkowski, Rola Platona i ruchu sokratycznego w kształtowaniu antycznego modelu filozoficznego życia, w: Filozofia jako sztuka życia. Teorie, modele i wzorce dla doradztwa filozoficznego, red. A. Woszczyk, D. Olesiński, Katowice 2013, s. 30.

${ }^{4}$ Nie znaczy to, że przed Sokratesem problematyka etyczna, czy też problematyka wyboru i wartości określonego sposobu życia, nie stanowiła przedmiotu filozoficznych badań. Można tutaj przywołać przykładowe prace, które tę kwestię podejmują: J. Gajda, Teorie wartości w filozofii przedplatońskiej, Wrocław 1992, passim; D. Dembińska-Siury, Człowiek odkrywa człowieka. O poczatkach 


\section{sposób życia ściśle związany z tym dyskursem, który ów egzystencjalny model uzasadnia 5 . „Egzystencjalny” wymiar filozofii nie ogranicza się do teoretycznej wiedzy o obyczajach czy do etyki norm. Owszem, tę wiedzę zakłada, ale jednocześnie okazuje się być „etyką zrealizowaną”, prakty- kowaną i wpisaną w obyczaje filozofa, inaczej mówiąc: uprawianą przez}

greckiej refleksji moralnej, Warszawa 1991, s. 112, 122-130, 137. Druga z zacytowanych autorek twierdzi, że to właśnie u pitagorejczyków po raz pierwszy spotykamy „świadome dążenie do wewnętrznej przemiany siebie", które obecne jest też w myśli Heraklita czy Empedoklesa, gdzie zwłaszcza ten ostatni poprzedził Platona w jego dwóch drogach wznoszenia się do Dobra: przez cnoty i przez poznanie. Por. D. Dembińska-Siury, Demokrytejska nauka szczęśliwego życia, w: J. Gajda, A. Orzechowski, D. Dembińska-Siury, Prawda - język - szczęście. Studia z filozofii starożytnej, Wrocław 1992, s. 108 138. Natomiast Bruno Snell zauważa, że: „podobnie jak tragedia attycka, filozofia pyta o działanie ludzi, o dobro. Dialogi Platona kontynuują w formie teoretycznej dyskusje bohaterów tragedii” (B. Snell, Odkrycie ducha. Studia o greckich korzeniach europejskiego myślenia, przeł. A. Onysymow, Warszawa 2009, s. 167).

Teza wyrażona powyżej i wywodząca „przynajmniej od czasów Sokratesa” genezę ścisłego związku między teoretycznym dyskursem oraz sposobem życia może mieć swe źródło w słowach Cycerona czy Diogenesa Laertiosa. Drugi z wymienionych zauważa: „był też Sokrates pierwszym filozofem, który rozprawiał o tym, jak najlepiej żyć" (Diogenes Laertios, Żywoty i pogląy stynnych filozofów, II, 5, 20, przeł. I. Krońska i in., Warszawa 2004, s. 88). Diogenes stwierdza dalej, że Sokrates doszedł do przekonania, iż badanie przyrody nie ma żadnego praktycznego znaczenia dla nas, ludzi, dlatego zajął się „roztrząsaniem zagadnień etycznych”. Por. M. T. Cicero, Rozmowy tuskulańskie, V 4, 10, w: M. T. Cicero, Księgi akademickie. O najwyższym dobru i złu. Paradoksy stoików. Rozmowy tuskulańskie, przeł. W. Kornatowski, J. Śmigaj, Warszawa 1961, s. 688. We wspomnianej wyżej tezie chodzi raczej o nowatorstwo i specyfikę tego, co nazwać można „filozoficznym sposobem życia”, czy też „filozofią rozumianą jako sposób życia”. Te zaś zasadniczo różnią się od problematyki etycznej podejmowanej najpierw przez poezję, a następnie przez filozofię raczej w aspekcie wyłącznie spekulatywnym i „teoretycznym”.

${ }_{5} \mathrm{Na}$ temat rozumienia filozofii antycznej jako sposobu życia zob. J. Domański, Metamorfozy pojęcia filozofii, przeł. Z. Mroczkowska, M. Bujko, Warszawa 1996; J. Domański, „Scholastyczne” i „humanistyczne” pojęcie filozofii, Kęty 2005; J. Domański, Erazm i filozofia. Studium o koncepcji filozofii Erazma z Rotterdamu, Wrocław 1973; J. Domański, Tekst jako uobecnienie. Szkic z dziejów myśli o piśmie i książce, Kęty 2002; P. Hadot, Czym jest filozofia starożytna?, przeł. P. Domański, Warszawa 2000; P. Hadot, Filozofia jako ćwiczenie duchowe, przeł. P. Domański, Warszawa 2003; P. Hadot, Twierdza wewnętrzna: wprowadzenie do „Rozmyślañ” Marka Aureliusza, przeł. P. Domański, Kęty 2004; P. Paczkowski, Filozoficzne modele życia w klasycznym antyku (IV w. p.n.e.), Rzeszów 2005; P. Paczkowski, Jedność filozofii Platona, Rzeszów 1998; J. Gwiazdecka, Etyka Platona. O formie platońskiej refleksji moralnej, Kęty 2003; por. J. Skrzypek-Faluszczak, Ocalenie od zła w filozofii Platona, Kraków 2010. 
niego „sztuką życia”" . Aby być filozofem, nie wystarczy zatem wiedzieć, jak przejść przez życie. Należy żyć w pełnej zgodzie z tą wiedzą ${ }^{7}$.

W dalszej części chciałbym przede wszystkim wskazać na kilka elementarnych założeń (cech), które - mimo różnorodności i specyfiki form jej realizacji ${ }^{8}$ - muszą znajdować się u podstaw filozofii rozumianej jako sposób życia, by umożliwić konsekwentne jej praktykowanie. Z drugiej zaś strony owe cechy powinny również odpowiadać określonym „predyspozycjom” po stronie jednostki. Dlatego też skoncentruję się głównie na tym, jakie cechy filozoficznych modeli życia, a także jakie aspekty ludzkiej kondycji należy przyjąć, by konkretna jednostka mogła realizować tak rozumianą filozofię - żyć na sposób filozoficzny.

\subsection{Spójna tożsamość i życiowy projekt jako fundament filozoficznej egzystencji}

Zamiar praktykowania określonego sposobu życia opiera się na akceptacji istnienia spójnej tożsamości, której fundamentalną cechą jest to, że daje się formować według założonego modelu. Wydaje się bowiem, że bez przyjęcia tych dwóch zasadniczych cech człowieka, czyli: trwałej tożsamości i możliwości jej konsekwentnego teleologicznego formowania, trudno mówić o jego funkcjonowaniu w ramach filozoficznego sposobu życia. Widać to wszędzie tam, gdzie realizacja określonego egzystencjalnego modelu wymagała czasu ${ }^{9}$, pracy nad sobą ${ }^{10}$, pokonania wielu przeciwności ${ }^{11}$ i długotrwałego osobistego zaangażowania. To znamienne,

6 Zob. P. Hadot, Czym jest filozofia starożytna?, dz. cyt., s. 23-27.

7 Zob. J. Domański, Metamorfozy pojęcia filozofii, dz. cyt., s. 11.

8 Zob. P. Paczkowski, Filozoficzne modele życia w klasycznym antyku..., dz. cyt., s. 53-166; por. P. Hadot, Czym jest filozofia starożytna?, dz. cyt., s. 85-221.

9 Zob. Epiktet, Diatryby, I.4, w: Epiktet, Diatryby. Encheiridion z dodaniem Fragmentów oraz Gnomologium epitetowego, przeł. L. Joachimowicz, Warszawa 1961, s. 15-19.

10 Efektem takiej pracy nad sobą może być sokratejskie „nieodczuwanie potrzeby” („poprzestawanie na małym”) czy „wstrzemięźliwość”. Zob. Ksenofont, Wspomnienia o Sokratesie, I 5, IV 5, w: Ksenofont, Pisma sokratyczne, przeł. L. Joachimowicz, Warszawa 1967, s. 58-60.

11 Zob. Marek Aureliusz, Rozmyślania (do siebie samego), 1.5, 7.61, 7.64, przeł. K. Łapiński, Warszawa 2011, s. 36, 142, 142-143; por. Epiktet, Diatryby, I.24, I.25, I.30, dz. cyt., s. 76-78, 79-83, 
że w postulatach filozoficznych szkół życia trudno odnaleźć opis wzorców ucieleśnionych przez realną osobę. Prawie wszystkie szkoły zgodne są również co do tego, że postać mędrca jest rzadkością ${ }^{12}$. Pojawiająca się apoteoza stanu finalnego spełnienia konkretnego wzorca miała służyć raczej celom parenetycznym ${ }^{13}$. Prezentacja ideału mędrca stanowiła zachętę i motywację do ciągłego doskonalenia. Nigdy nie była samosatysfakcją pieczętującą koniec pracy nad sobą ${ }^{14}$. Jak trafnie ujął to Pierre Hadot, „wiedziano, że mądrości nigdy nie uda się zrealizować w sobie jako stanu trwałego i definitywnego. Miano jednak nadzieję osiągnąć go przynajmniej w niektórych, szczęśliwszych chwilach; mądrość była normą transcendentną kierującą działaniem"15. Godny odnotowania jest ten swoisty „,infinityzm” w realizacji filozoficznego modelu życia. Liczył się dla niego każdy krok, każdy etap i każdy dzień. Choć finalne doświadczenie szczęścia było zawsze związane z tym, co miało dopiero nadejść, to nie miało ono nic wspólnego ze ślepym dążeniem ku utopijnej przyszłości nigdy niespełnionego jutra. Przykład znajdujemy u Arystotelesa, który życiu filozoficznemu - jako jedynemu - przypisał prerogatywy szczęścia autarkicznego. Człowiek więc potrafi je osiągnąć, ale tylko w pewnych momentach i tylko na sposób dla niego możliwy ${ }^{16}$. Dla filozoficznego mo-

102-103; por. Epikur z Samos, Listy oraz wybór świadectw, opr. K. Pawłowski, Warszawa 2015, s. 133; por. L. A. Seneka, Listy moralne do Lucyliusza, LXXV, przeł. W. Kornatowski, Warszawa 1998, s. 308-312.

12 Zgodni byli również co do tego, że mędrcem na pewno był Sokrates. Wyjątek stanowili tutaj epikurejczycy, którzy czcili Epikura jako mędrca par excellence. Zob. P. Hadot, Czym jest filozofia starożytna?, dz. cyt., s. 283.

13 Świadectwem tego są pochwały Pirrona, Epikura czy Chryzypa. Zob. G. Reale, Historia filozofii starożytnej, t. 3: Systemy epoki hellenistycznej, przeł. E. I. Zieliński, Lublin 2004, s. 35-37.

14 Jak zauważa Kwintylian, wielu „dawnych autorów” uznawało, że nie istniał człowiek zasługujący na miano prawdziwego mędrca. Niemniej jednak autorzy ci pozostawili w swych pismach „przepisy prawdziwej mądrości”. Zob. M. F. Kwintylian, Kształcenie mówcy, ks. I, wstęp, 19, tł. M. Brożek, Warszawa 2002, s. 75.

15 P. Hadot, Filozofia jako ćwiczenie duchowe, dz. cyt., s. 289. Hadot zauważa dalej, że na tym właśnie polegały paradoks i wielkość filozofii antycznej, że całkowita mądrość była dla niej czymś nieosiągalnym, co jednocześnie nie zwalaniało z konieczności czynienia postępów duchowych.

16 Zob. Arystoteles, Etyka nikomachejska, 1177 b, tł. D. Gromska, w: Arystoteles, Dzieła wszystkie, t. 5, Warszawa 1996, s. 291-292; por. Arystoteles, Metafizyka, 1072 b, tł. K. Leśniak, w: Arystoteles, Dzieła wszystkie, t. 2, Warszawa 1990, s. 813-814. 
delu życia typowy był więc progres, ciągła droga własnego doskonalenia, nieustanny proces przekształcania i formowania swej duszy w oparciu o przyjęty cel ${ }^{17}$. Tym sposobem każdą życiową decyzją filozof budował siebie i swoją elementarną tożsamość. Całe życie było dla niego zadaniem polegającym na konstruowaniu własnego obrazu.

Jednakże wyjątkowość filozoficznego sposobu życia powodowała, że inaczej trzeba zdefiniować wspomniany już „infinityzm”. Cel takiego życia nie odsuwał się w bliżej nieokreśloną przyszłość. Należałoby raczej powiedzieć, że postęp w cnocie sprawiał, iż filozof doświadczał czegoś w rodzaju „eschatologicznego" napięcia między ,już” a „jeszcze nie”. Owo "jeszcze nie" jest zrozumiałe i polega na ciągłym oczekiwaniu na finalne spełnienie. Ale filozoficzne „już” oznaczało również, że w danym momencie praktykowania określonego modelu życia, w konkretnej sytuacji cnotliwego postępowania, w maksymalnej, na miarę ludzkiej natury, realizacji przyjętego egzystencjalnego modelu, filozof - właśnie „już” doświadcza szczęścia ${ }^{18}$ i spełnienia tego modelu. Kiedy bowiem przekracza on siebie, swe ludzkie ograniczenia, kiedy nie toleruje własnych słabości, kiedy wreszcie konsekwentnie żyje tak, jak postanowił żyć już wtedy doznaje spełnienia na miarę możliwości własnej natury ${ }^{19}$. Ale niezbywalną cechą człowieczeństwa jest to, że owym spełnieniem nie można na stałe zawładnąć. Być może dlatego, że to już obszar „boski” (jak boskim atrybutem była pełnia mądrości), do którego dystans wyznacza skala trudu niezbędnego przy chwilowym choćby jego doświadczeniu. Dlatego niczym Eros z Platońskiej Uczty, filozof zdobywa i traci, „rodzi się" $i$ „umiera”, posiada i nie posiada jednocześnie ${ }^{20}$. Właśnie tak

17 Zob. Epiktet, Diatryby, III.12, dz. cyt., s. 249-251.

18 Jak twierdzi Giovanni Reale, dla Greków szczęście jest „sposobem bycia”, dlatego tak ściśle łączy się z cnotą. Zob. G. Reale, Zło nękające współczesnego człowieka i lekarstwo, jakie można na nie znaleźć w myśli antycznej, tł. E. I. Zieliński OFMConv, „Ethos” 14 (2001) nr 4 (56), s. 27.

19 Zob. Marek Aureliusz, Rozmyślania..., dz. cyt., 4.49, 5.1, 5.29, 6.58, 8.47, 9.11, 10.32, 12.1, s. $88,90,104,126,160-161,173,197-198,219-220$.

20 Zob. Platon, Uczta, przeł. W. Witwicki, w: Platon, Dialogi, t. 2, Kęty 2005, s. 68-69; por. K. Albert, O platońskim pojęciu filozofii, przeł. J. Drewnowski, Warszawa 1991, passim; por. K. Albert, Wprowadzenie do filozoficznej mistyki, przeł. J. Marzęcki, Kęty 2002, s. 59-63; por. K. Albert, Studia o historii filozofii, przeł. B. Baran, J. Marzęcki, Warszawa 2006, s. 213-222. 
proponuję rozumieć filozoficzny cel i projekt realizowany przez całe życie: jest to projekt oparty na jednostkowej tożsamości oraz zdolności jej konsekwentnego, spójnego konstruowania. W ten sposób filozoficzny etos nabierał cech harmonii i jednolitości. Nie był on serią obojętnych i przypadkowych epizodów. Nie stanowił również mozaiki całkowicie dowolnych zachowań i działań, które mogłyby pozostawać bez wpływu na ostateczny kształt danej „osoby”21. Życie filozoficzne polegało w swej istocie

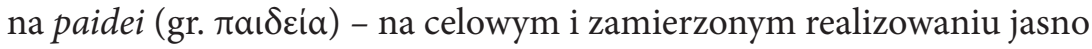
określonego modelu, na wzór którego należało ukształtować własną duszę.

\subsection{Rola psyche i radykalizm życia filozofa}

Filozoficzny sposób życia był określonym projektem mającym stanowić drogę do szczęścia. Wsparty racjonalnym uzasadnieniem, wiódł przez trud (ponos, gr. $\pi$ óvos), wystarczanie samemu sobie (autarkia,

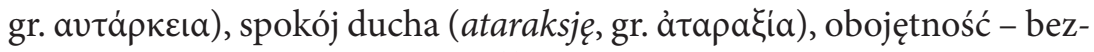
afektywność (apatia, gr. ảđá $\theta \varepsilon ı \alpha)^{22}$ czy też przezwyciężenie bólu fizycznego (aponia, gr. ađoviá). Żyć na sposób filozoficzny znaczyło konsekwentnie realizować wybraną opcję egzystencjalną. Właśnie tak naszkicowany obraz filozoficznego życia łączy antycznych przedstawicieli, od Sokratesa aż po szkoły hellenistyczne. Mimo wyraźnych różnic ruch sokratyczny miał kilka wspólnych cech, z których najważniejszą był nacisk położony na dobre (szczęśliwe) życie i decydującą w takim życiu rolę cnoty oraz wiedzy ${ }^{23}$. Choć w ramach filozoficznego modelu życia konkurowały ze

21 Cudzysłów, w który opatrzyłem ten termin, miałby uwzględniać uwagę, jaką poczynił Władysław Seńko, twierdząc, że samo pojęcie „osoby”, wzięte w znaczeniu „osobowości”, obce jest racjonalizmowi greckiemu. Nawiązując do Historii filozofii greckiej Eduarda Zellera, Seńko twierdzi, że łacińskie, średniowieczne słowo persona nie ma nic wspólnego z greckim pros opon (gr. $\pi \rho \circ \sigma \omega ́ \pi \omega v$ ). Tym samym definicja osoby zaproponowana przez Boecjusza nie odpowiada żadnej rzeczywistości znanej Grekom. Zob. W. Seńko, Jak rozumieć filozofię średniowieczną, Kęty 2001, s. 13.

${ }^{22}$ Termin ten jest bardzo trudny do przełożenia, dlatego proponuję tutaj jedynie przybliżone jego znaczenie właśnie jako „obojętność-bezafektywność”.

${ }^{23}$ Istotny jest tutaj obraz rozumu porównanego do „twierdzy”: zob. Epiktet, Diatryby, IV.1, IV.5, dz. cyt.; por. M. T. Cicero, Rozmowy tuskulańskie, II.58, dz. cyt., s. 349, 383; por. Platon, Państwo, 560 B-C, w: Platon, Państwo. Prawa (VII ksiag), przeł. W. Witwicki, Kęty 2001, s. 269. 
sobą różne wizerunki filozofa, to jednak model ten zawsze opisywany będzie jako życie zgodne z prawdziwą naturą człowieka ${ }^{24}$. Kontynuując tę myśl, należałoby dodać, że fundamentem owej natury musiało być przekonanie o posiadaniu własnej tożsamości, która podatna była na różnorodne formowanie. Ową tożsamość trzeba by chyba ulokować w tym, co

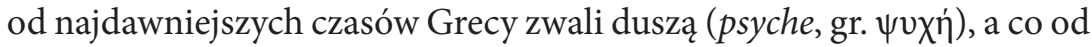
Sokratesa zyskuje zupełnie nowe wyobrażenie ${ }^{25}$. Giovanni Reale - idąc za sugestią Burneta i Taylora - uznaje wręcz, że Sokrates był odkrywcą duszy pojętej jako „ja” i jako „świadomość”26. Odtąd istoty człowieka należało szukać właśnie w jego psyche, a troszczyć się o siebie znaczyło od teraz troszczyć się o duszę, czyli poznać samego siebie i znaleźć środki pozwalające stać się możliwie najlepszym ${ }^{27}$. Natomiast Bruno Snell zauważa, że to właśnie od Sokratesa prawdziwego szczęścia upatrywano w szczęściu duszy, która jest nieśmiertelna, a dzięki temu zdolna osiąg-

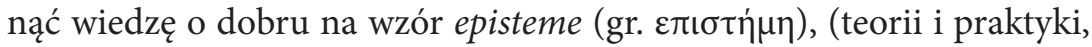
wiedzy nieodłącznie związanej z możnością działania) ${ }^{28}$. I nawet jeśli następcy Sokratesa różnili się w rozumieniu tego „jądra człowieczeństwa”, jak na przykład Pirron mówiący o „jaźni opanowanej przez umysł

24 Zob. L. A. Seneka, O życiu szczęśliwym, II-IV, VIII, w: L. A. Seneka, Dialogi, przeł. L. Joachimowicz, Warszawa 1998, s. 159-164, 168-170.

25 Jak pisze Stefan Swieżawski, u Sokratesa nie występuje jeszcze wyraźne pojęcie „duchowości duszy”; ono pojawi się dopiero u Platona. Niemniej jednak „u Sokratesa znajdujemy elementy przygotowujące tę koncepcję". Zob. S. Swieżawski, Dzieje europejskiej filozofii klasycznej, WarszawaWrocław 2000, s. 70; por. W. Jaeger, Paideia. Formowanie człowieka greckiego, przeł. M. Plezia, H. Bednarek, Warszawa 2001, s. 589-593; por. T. A. Szlezak, O nowej interpretacji platońskich dialogów, przeł. P. Domański, Kęty 2005, s. 110-126.

${ }^{26}$ Reale zauważa, że wraz z Sokratesem dokonała się „epokowa rewolucja”, która doprowadziła Greków do ujęcia natury człowieka jako różnej od ciała, a tożsamej z duszą rozumianą jako „wyraz osobowości intelektualnej i moralnej” (G. Reale, Pojęcie człowieka, troski o duszę i duchowego Erosa jako przesłanie myśli antycznej dla człowieka współczesnego, tł. P. Mikulska, „Ethos” 13 (2000) nr 1-2 (49-50), s. 34).

27 Zob. G. Reale, Historia filozofii starożytnej, t. 1, dz. cyt., s. 318-325. Sokratejskie „dbanie o duszę” jest dla Realego w najpełniejszym tego słowa znaczeniu „dbaniem o siebie”. Zob. G. Reale, Pojęcie człowieka, troski o duszę i duchowego Erosa..., dz. cyt., s. 37.

28 Zob. B. Snell, Odkrycie ducha..., dz. cyt., s. 230-234. 
niepodlegający doznaniom"29, czy też Zenon i Chryzyp postulujący życie według "prawego rozumu” (orthos logos, gr. o $\rho \theta \omega \varsigma \lambda \lambda$ ó $о \varsigma)^{30}$, to jednak wszyscy pozostawali zgodni w tym, że życie filozofa powinno być konsekwentnie realizowanym projektem ${ }^{31}$. Tej konsekwencji nie można odmówić nawet - a może przede wszystkim - cynickim postulatom bez-

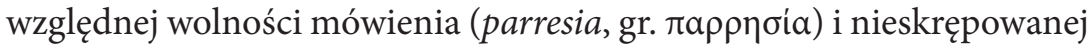

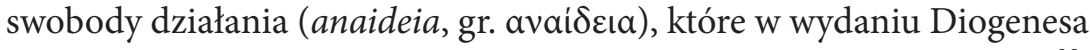
częstokroć mogły wydawać się szczerością graniczącą z wynaturzeniem ${ }^{32}$. Zatem filozof każdego dnia i każdym czynem budował siebie w sposób nieprzypadkowy, ale ściśle określony i uzależniony od fundamentalnego egzystencjalnego wyboru.

Projekt życia filozofa nie wyczerpywał się w jakimś konkretnym momencie, w zbiegu wyjątkowych okoliczności lub chwilowym natężeniu pozytywnych emocji. Nie ograniczał się też do żadnego specjalnego zakresu działań. Filozofem było się przez cały czas. Nie można było być filozofem „na chwilę", nie można było „sprawiać wrażenia” „bycia filozofem”’33. Radykalizm w prowadzeniu pewnego sposobu życia był tutaj bezlitosny dla wszelkiej imitacji i złudy. Skrajny przykład tej życiowej konsekwencji

29 W ten sposób cechę „nieodczuwania” u Pirrona charakteryzuje Adam Krokiewicz. Zob. A. Krokiewicz, Arystoteles, Pirron i Plotyn, Warszawa 1974, s. 125.

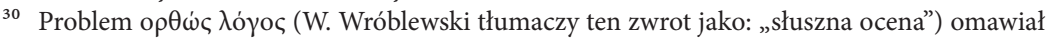
również Arystoteles. W Etyce wielkiej zauważa, że cnota to popęd do moralnego piękna z udziałem właśnie „słusznej oceny”. Zob. Arystoteles, Etyka wielka, 1198 a, tł. W. Wróblewski, w: Arystoteles, Dzieła wszystkie, t. 5, Warszawa 1996, s. 348-349.

31 Istnienie takiego „projektu”, jak i samej „sztuki życia” kwestionują sceptycy. Zob. Sekstus Empiryk, Zarysów Pirrońskich księga pierwsza, druga i trzecia, ks. III, 24-31, przeł. A. Krokiewicz, Kraków 1931, s. 150-169. Natomiast w traktacie Przeciw etykom Sekstus pisze, że możliwe jest, iż ci, którzy wybierają zawieszenie sądu w każdej sprawie, wiodą godziwe życie. Zob. Sekstus Empiryk, Przeciw etykom, 168, w: Sekstus Empiryk, Przeciw fizykom, Przeciw etykom (Adversus mathematicos IX-XI), przeł. Z. Nerczuk, Kęty 2010, s. 217.

32 Pojęcie anaideia (gr. $\alpha v \alpha i ́ \delta \varepsilon l \alpha$ ) może być tłumaczone jako „bezwstyd”, co pomaga zrozumieć kierunek i charakter tej „szczerości graniczącej z wynaturzeniem”. Zob. Diogenes Laertios, Żywoty i poglądy stynnych filozofów, dz. cyt., VI 2, 22, 34, 61, 69, s. 322-323, 328, 342, 346-347.

${ }_{33}$ Epikur twierdził, że kto stał się mędrcem, nie może już nigdy zmienić usposobienia. Namiętności mogą go trapić mocniej niż innych ludzi, ale nie przyniesie to żadnego uszczerbku jego mądrości. Zob. Epikur z Samos, Listy oraz wybór świadectw, dz. cyt., s. 34. 
odnajdujemy chociażby u stoików, których ideał mędrca nie dopuszczał żadnego stopniowania. Albo jest się mędrcem, albo głupcem ${ }^{34}$. Wyjątkowa siła każdego z filozoficznych sposobów życia leżała również w tym, że były one zdolne diametralnie przemienić ludzkie życie. Niosły z sobą całkowitą jego metamorfozę ${ }^{35}$. To też świadczyło o specyficznej kondycji człowieka, podatnej na ciągłe formowanie i gruntowną przemianę. Ten dominujący życiowy cel, niczym jasno określony projekt, organizował wszelkie działania filozofa. W sposób paradygmatyczny wyznaczał skalę wartości i zakres tego, co słuszne ${ }^{36}$. Nie tylko łączył życie w harmonijną całość, ale również decydował o tym, czy dany czyn, opcja, możliwość zachowania są godne wyboru, czy też odrzucenia. Wszystko, co robił filozof, miało go zbliżać do celu, który czynił sensownym całe życie.

Modele filozoficznej egzystencji cechowała również ponadjednostkowość. Były one w stanie urzec swym pięknem, wartością i potęgą, a następnie zachęcić rzesze ludzi do podporządkowania im swojego życia. Dzięki sile swego oddziaływania stawały się więc projektami ogólnoludzkimi, wokół których organizowały się filozoficzne szkoły życia ${ }^{37}$. Ta ponadjednostkowość określonego modelu życia mogła pojawić się wyłącznie na bazie podobieństwa ludzkich predyspozycji, potrzeb i zdolności ${ }^{38}$. Nawet jeśli nie ma podstaw, by użyć tutaj pojęcia ludzkiej „natury”, to na pewno można mówić o jakiejś międzyludzkiej wspólnocie cech, dążeń i możliwości. Tylko w ten sposób daje się mówić o powszechności określonego modelu życia i jego oddziaływaniu na pewną zbiorowość ludzi.

${ }^{34} \mathrm{Na}$ tej podstawie - jak zauważa Adam Krokiewicz - stoicy dzielili ludzi na zupełnie dobrych (spoudaioi, gr. $\sigma \pi o v \delta \alpha i o \iota)$ i zupełnie złych (phauloi, gr. $\varphi \alpha v ́ \lambda o \iota)$. Zob. A. Krokiewicz, Zarys filozofii greckiej, Warszawa 2000, s. 467.

35 Zob. P. Hadot, Filozofia jako ćwiczenie duchowe, dz. cyt., s. 223-235.

36 Zob. L. A. Seneka, O niezłomności mędrca, X, w: L. A. Seneka, Dialogi, dz. cyt., s. 496-498.

37 Zob. O. Gigon, Główne problemy filozofii starożytnej, przeł. P. Domański, Warszawa 1996, s. $67-71$.

38 Fundamentem „ponadjednostkowości” filozoficznego modelu życia jest dusza. Zdaniem Realego to Sokrates jest: „odkrywcą tego, że człowiek istnieje jako dusza. [...] Aby zobaczyć i poznać człowieka, trzeba wydobyć jego duszę i kontemplować ją. Prawdziwym człowiekiem jest bowiem dusza, ciało jest tylko jej narzędziem" (G. Reale, Zło nękające współczesnego człowieka i lekarstwo..., dz.cyt., s. 32). 
Pewien model życia budował więc wspólnotę osób, ale jednocześnie odpowiadał tym cechom w nich samych, które stanowiły o ich podobieństwie i głębokiej jedności ${ }^{39}$.

Podsumowując: prowadzenie filozoficznej egzystencji i konstruowanie jej etosu wydaje się niemożliwe bez przyjęcia spójnej i trwałej tożsamości wraz z możliwością jej rozumnego formowania. To ona pozwalała na kształtowanie życia według założonych celów, których powszechność i ponadjednostkowość umożliwiała budowanie wspólnoty filozofów i filozoficznych szkół.

\section{2. „Współczesność” - między nowoczesnością a ponowoczesnością}

Zupełnie inaczej niż w starożytności przedstawia się sytuacja w epoce „współczesnej”. Proponuję scharakteryzować ją w oparciu o relację między nowoczesnością a ponowoczesnością. Przy jej prezentacji - jako pewnym schematem - posłużę się opisem zaproponowanym przez Zygmunta Baumana. Otóż charakteryzuje on ponowoczesność jako całkowite zaprzeczenie nowoczesności ${ }^{40}$. Radykalna opozycyjność obu z wymienionych wyraźnie widoczna jest zwłaszcza na tle porównania typowych dla nich „wzorców osobowych"41. Jak twierdzi Bauman, ponowoczesny styl życia charakteryzuje niespójność, niekonsekwencja postępowania, fragmentaryzacja i epizodyczność różnych sfer aktywności. Nie ma struktur społecznych, które wyznaczałyby ramy realizacji „projektu życiowego" ${ }^{\text {"22 }}$. Życie staje się zbiorem epizodów o przypadkowej kolejności. Każdy z nich jest zamkniętą całością i nie zostawia następstw. Życie

39 Zob. Epikur z Samos, Listy oraz wybór świadectw, dz. cyt., s. 76.

40 Stosunek postmodernizmu do modernizmu nie jest jednoznaczny także w wypowiedziach samego Baumana. Zob. S. Kowalczyk, Idee filozoficzne postmodernizmu, Radom 2004, s. 12-13.

${ }^{41}$ Istotnym filozoficznym problemem na gruncie postmodernizmu jest też koncepcja prawdy. Zwolennicy postmodernizmu kwestionują nie tylko jej istnienie (zwłaszcza w wymiarze obiektywnym), ale również psychologiczną potrzebę. Zob. S. Kowalczyk, Pytanie o prawdę w ponowoczesności, w: Nowoczesność/ponowoczesność. Fenomen i wyzwanie, red. J. Wojciechowski, Warszawa 2009, s. $43-52$.

42 Zob. Z. Bauman, Dwa szkice o moralności ponowoczesnej, Warszawa 1994, s. 14. 
porównane zostaje do serialu, którego odcinki charakteryzuje tymczasowość osiągnięć, niestałość zainteresowań, ulotność wartości i doraźność celów. Skutkuje to tym, że problematyczne staje się jakiekolwiek osobowe samookreślenie. Nie ma już znaczenia konsekwencja i dążenie do wyznaczonego sobie celu. Zamiast nich atutem miałaby być elastyczność zainteresowań, szybkość ich zmiany, giętkość przystosowania czy „umiejętność zapominania tego, co już wyszło z użycia”43. W tym świetle trudno byłoby w ogóle mówić o jednostkowej i ściśle określonej tożsamości ${ }^{44}$. Im mniej dokładnie tożsamość jest zdefiniowana, tym lepiej dla jej posiadacza ${ }^{45}$. Tożsamość jest wręcz tym, co człowieka krępuje, ogranicza. Jak zauważa Aleksandra Kunce, postmodernistycznie rozegrana tożsamość zostaje wyprowadzona z własnej mocy uchwycenia siebie jako siebie. Zostaje rozpisana na doraźne próby identyfikacyjne ${ }^{46}$. Osobowość staje się kalejdoskopem kolejnych wcieleń. Jedną z najistotniejszych cech ponowoczesnego modelu życia jest rozpad zasadniczego "projektu życiowego” na serię samoistnych epizodów, w żaden sposób ze sobą niepowiązanych lub nawet zupełny brak takiego projektu. Nie ma głównego celu, do którego należałoby dążyć. Nie ma modelu, z którym

43 Zob. Z. Bauman, Dwa szkice o moralności ponowoczesnej, dz. cyt., s. 16.

44 Jedną z przyczyn braku owej spójnej, konsekwentnie budowanej tożsamości jest zapewne postulowana przez postmodernizm negacja ludzkiej natury. Zob. S. Kowalczyk, Idee filozoficzne postmodernizmu, dz. cyt., s. 65-75.

${ }^{45}$ Trzeba też zauważyć, że w niektórych miejscach Bauman nie tylko nie neguje samego faktu posiadania tożsamości, ale zwraca nawet uwagę, że owa „ponowoczesna tożsamość” ma być tak płynna i nieokreślona jak sam postmodernizm. Dzieje się tak dlatego, że: „tożsamość, która może być myląca, domniemana, choć także - i to się może zdarzyć - niekłamana, zawsze pozostanie przeze mnie przypisana” (Z. Bauman, Etyka ponowoczesna, przeł. J. Bauman, J. Tokarska-Bakir, Warszawa 1996, s. 122). Dalej Bauman pisze o „swobodach wyboru tożsamości”. Zob. Z. Bauman, Etyka ponowoczesna, dz. cyt., s. 160-161. Źródeł przemiany tego postrzegania tożsamości upatruje również w „indywidualizacji”, która zmienia tożsamość z „danej” w „zadaną”. Zob. Z. Bauman, Płynna nowoczesność, przeł. T. Kunz, Kraków 2006, s. 49-51. Natomiast Stanisław Czerniak mówi o „tożsamości epokowej” na gruncie postmodernizmu. Zob. S. Czerniak, Świadomość postmodernistyczna?, w: Postmodernizm a filozofia. Wybór tekstów, red. S. Czerniak, A. Szahaj, Warszawa 1996, s. 17.

46 Zob. A. Kunce, Tożsamość i postmodernizm, Warszawa 2003, s. 42. „Tożsamość jest w samym toku rozgrywania, rozsadzania, scalania, zakorzeniania, dekonstruowania, zmieniania” (A. Kunce, Tożsamość i postmodernizm, dz. cyt., s. 43). 
należałoby się identyfikować i który stawałby się wzorem życiowego spełnienia. Skutkiem tego jest nie tylko dezintegracja tożsamości, ale również społecznych więzi i zależności ${ }^{47}$. Nie ma już mowy o wspólnocie celów, o jedności życiowego projektu. Tak samo jak stabilności pozbawiona została jednostkowa tożsamość, tak również zanikowi uległy wszelkie głębsze relacje międzyludzkie ${ }^{48}$. Tak rozumiane ponowoczesne wzorce osobowe Bauman egzemplifikuje za pomocą obrazu spacerowicza, włóczęgi, turysty i gracza. Natomiast wzorzec nowoczesny - którego całkowitym zaprzeczeniem jest ponowoczesność - oddaje poprzez model pielgrzyma. Nowoczesność charakteryzowała się bowiem - jak zauważa Bauman - z góry wyznaczonym celem, który należało osiągnąć, a w drodze do którego dokonywało się konsekwentne budowanie tożsamości. W życiu pielgrzyma nie ma miejsca na kroki, które do celu nie zbliżają. Nie ma w nim czynów obojętnych. Pielgrzymką było życie jako całość. Nastawienie na spójność i konsekwencję zakładało z kolei, że czyny pozostawiają trwały ślad i że ślady te się kumulują. Plan był na całe życie. To projekt, który zakładał możliwość ciągłego wysiłku, spójnego i konsekwentnego, podporządkowanego na przestrzeni życia jednemu, raz obranemu i niezmiennemu odtąd celowi ${ }^{49}$. Zaprojektowaną tożsamość można było budować, zakładając, że dzisiejsze dokonania służą urzeczywistnieniu projektu całościowego niczym inwestycje na przyszłość. Jak zauważa Anthony Giddens, tak rozumiana tożsamość była projektem refleksyjnym, za który jednostka stawała się odpowiedzialna. Jesteśmy nie tym, czym jesteśmy, ale tym, co z siebie zrobimy ${ }^{50}$. Obecność takich

47 Zob. Z. Bauman, Tożsamość. Rozmowy z Benedetto Vecchim, przeł. J. Łaszcz, Gdańsk 2007, s. 14 .

48 Zob. J.-F. Lyotard, Kondycja ponowoczesna. Raport o stanie wiedzy, przeł. M. Kowalska, J. Migasiński, Warszawa 1997, s. 59.

49 Zob. Z. Bauman, Dwa szkice o moralności ponowoczesnej, dz. cyt., s. 13.

50 A. Giddens, Nowoczesność i tożsamość. „Ja” i społeczeństwo w epoce późnej nowoczesności, tł. A. Szulżycka, Warszawa 2010, s. 107. Dalej zauważa, że to, kim stanie się jednostka, wynika z jej starań zmierzających do jej rekonstrukcji. „Oznacza to więcej niż po prostu „lepsze poznanie samego siebie”. Samozrozumienie jest podporządkowane szerszemu i bardziej fundamentalnemu celowi, jakim jest wytwarzanie i odtwarzanie spójnego i satysfakcjonującego poczucia tożsamości" (A. Giddens, Nowoczesność i tożsamość..., dz. cyt., s. 108). 
„projektów” (narracji, metanarracji) sprawiała, że człowiek nowoczesny „żył-z-projektem”, „w-cieniu-projektu” i „ku-projektowi”. To powodowało, że tożsamość była czymś budowanym poziom po poziomie, piętro po piętrze $^{51}$. Tak rozumianą tożsamość charakteryzuje również to, że odwołuje się ona do możliwości wartościowania (stanowiska w pewnych moralnych kwestiach), ale i to, że odnosi się do pewnej wspólnoty ${ }^{52}$.

\section{Aktualność lub dezaktualizacja filozofii jako modelu życia}

Dopiero w obliczu naszkicowanej powyżej specyfiki filozofii antycznej, jak również sposobu rozumienia „współczesności”, można zapytać o jakiekolwiek łączące je relacje w aspekcie ewentualnej „aktualności”. Pierwsza z takich relacji dostrzegalna jest wówczas, gdy traktuje się myśl starożytną na sposób „teoretyczny”, czyli jako próbę racjonalnego wyjaśnienia rzeczywistości. Mieczysław A. Krąpiec sądzi na przykład, że w ten sposób pojmowana filozofia - w swej klasycznej odsłonie jako namysł nad bytem - pojawiła się właśnie w starożytności, a następnie utorowała drogę dla wielowiekowej refleksji metafizycznej ${ }^{53}$. Tę „teoretyczną aktualność" można również potraktować tak, jak czyni to Nicholas Fearn, który w poglądach i systemach filozoficznych dostrzega nie tyle rozwiązania konkretnych problemów, ile raczej pewne powtarzalne schematy i paradygmaty myślenia ${ }^{54}$. Wreszcie znamię tego typu „aktu-

51 Zob. Z. Bauman, Ponowoczesność, czyli dekonstruowanie nieśmiertelności, przeł. A. Szahaj, w: Postmodernizm a filozofia..., dz. cyt., s. 146-149.

${ }_{52}$ Zob. Ch. Taylor, Źródła podmiotowości. Narodziny tożsamości nowoczesnej, przeł. A. Lipszyc, Warszawa 2012, s. 58, 72.

53 Podkreśla on poznawczotwórczą rolę podstawowego pytania dia ti? („dla-czego?”) i odpowiedzi będącej próbą ukazania takiego bytowego czynnika, który gwarantuje filozoficzne, czyli ostateczne rozumienie. „Tak więc różnorodne stawianie pytań oraz udzielanie racjonalnych odpowiedzi decydują w wymiarze ostatecznym (bazowym) o klasyczności filozofii, jej właściwym rozumieniu, jej niewygasłej ciągłości i wiecznej młodości” (M. A. Krąpiec, Czym jest filozofia klasyczna?, w: W kręgu filozofii klasycznej, red. B. Dembiński, Katowice 2000, s. 23). Por. M. A. Krąpiec, Filozofia co wyjaśnia?, Lublin 1998, passim.

54 Zob. N. Fearn, Zenon i żótw. Jak myśla filozofowie, przeł. M. Pawlikowska, Warszawa 2007, passim. 
alności" mieści się również w sprecyzowanym chociażby przez Leibniza pytaniu o „filozofię wieczystą" (philosophia perennis) ${ }^{55}$.

Natomiast drugą z rozpatrywanych tutaj możliwości jest ta, która owej „aktualności” filozofii (zwłaszcza w jej antycznym wydaniu) będzie się dopatrywać w proponowanym przez nią modelu życia. Tej „aktualności” nie pojmuję tutaj jako imperatywu ponadczasowego kopiowania antycznych modeli życia, które wyrosły przecież w konkretnych kontekstach kulturowych, często będąc swoistą reakcją na społeczno-polityczne uwarunkowania. Dlatego też nie wskazuję żadnego z określonych modeli życia, który miałby zostać przeszczepiony na grunt współczesności. Takie jego potraktowanie faktycznie narażone byłoby na zarzut anachronizmu. Przestrzeni dla owej aktualności proponuję raczej szukać w specyficznej relacji między: z jednej strony zespołem określonych cech, przymiotów i predyspozycji, które definiują kondycję człowieka, a z drugiej - układem wartości, postaw i preferencji, które proponuje pewien sposób filozoficznego życia. Ta relacja ma bowiem fundamentalne znaczenie dla zrozumienia problemu ewentualnej „aktualności” filozoficznych modeli życia. Zauważmy bowiem pewną prawidłowość. Otóż filozofia traktowana jako pewien sposób życia mogła pojawić się przecież tylko na gruncie właściwie uposażonej kondycji człowieka (ludzkiej natury), ale również nie mogła być zupełnie obca ludzkim potrzebom i możliwościom. Taki ideał życia wręcz musiał być na wskroś „ludzki”. I nie przeczy temu fakt, że nie był to ideał pospolity, banalny w sensie łatwości urzeczywistnienia. Ten jego „ekskluzywizm” (atopiczność) świadczy właśnie o sile ludzkiego ducha zdolnego do samostanowienia. Dlatego relacja między konkretnym modelem życia a ludzką „naturą" właściwie uposażoną i predysponowaną do jego realizacji wydaje mi się tutaj kluczowa. Leży ona u najgłębszych podstaw funkcjonowania samej filozofii jako sposobu życia. Dostrzeżenie tej zależności pociąga za sobą również istotną

55 Jak zauważa Swieżawski, każdy konsekwentnie filozofujący człowiek przesądza już w swych wstępnych wyborach intelektualnych tę idealną filozofię, którą określa jako filozofię wieczystą, a która nie jest niczym innym, niż doprowadzoną do pełnego rozkwitu jego własną filozofią. Zob. S. Swieżawski, O filozofii wieczystej, w: S. Swieżawski, Prawda i tajemnica. Pisma filozoficzne, Warszawa 2007, s. 39 . 
konsekwencję. Otóż dzięki niej otwiera się możliwość pytania o aktualność właśnie tak rozumianej filozofii. Podkreślę to raz jeszcze. Nie konkretyzuję tutaj żadnego z klasycznych filozoficznych wzorców jako tego, który miałby aktualnie obowiązywać. Wskazuję jedynie na obecność zasadniczego schematu, pewnej struktury elementarnej zależności, która pozwala na realizację jakiejkolwiek modelowej relacji.

Właśnie na styku tej wyjątkowej odpowiedniości między modelem filozoficznej egzystencji a ludzkimi predyspozycjami można - jak sądzę - mówić o ewentualnej aktualności filozofii rozumianej jako praktykowanie pewnego sposobu życia ${ }^{56}$. Tę kwestię proponuję rozstrzygnąć, porównując nowoczesne i ponowoczesne „wzorce osobowe” (posługując się terminologią zaproponowaną przez Baumana), a następnie zestawiając je z antycznymi modelami filozoficznego życia. O aktualności filozofii rozumianej jako sposób życia można mówić tylko wówczas, gdy samą współczesność zdefiniujemy w kategoriach zaprezentowanej wyżej „nowoczesności”. Zauważmy, że tym, co łączy ją z antycznymi modelami filozoficznego życia, jest obecność „wzorców osobowych”, jak również odpowiadającej im pewnej koncepcji człowieka. Funkcjonują one w oparciu o tę samą fundamentalną relację, na której istnienie i kluczowe znaczenie kilkakrotnie wskazywałem. Nowoczesność cechuje się przede wszystkim istnieniem jednolitego „projektu na całe życie”, zbudowanego na trwałej, spójnej i konsekwentnie konstruowanej tożsamości. To właśnie w stopniu decydującym zbliża ją do sposobu funkcjonowania filozoficznych modeli życia.

A zatem ta zdolna do samokształtowania ludzka natura oraz nadający jej spójność i wyznaczający jej tożsamość zasadniczy życiowy projekt spra-

56 Aktualność filozofii antycznej widzi także Reale. Najpierw identyfikuje on dziesięć „błędów” współczesności (scjentyzm, ideologizm, praksizm, materialny dobrobyt, przemoc, zapomnienie o pięknie i miłości, zredukowanie człowieka do wymiaru materialnego, zapomnienie o celu oraz materializm), a następnie w mądrości antycznej odnajduje lekarstwo na te choroby. Zob. G. Reale, Zło nękające współczesnego człowieka i lekarstwo..., dz. cyt., s. 17-34. Podobną aktualność filozofii antycznej odnajduje w metaforze nawrócenia z Platońskiego Państwa i „modlitwie filozofa” z Platońskiego Fajdrosa. Zob. G. Reale, Dwa przesłania Platona dla ludzi wszystkich czasów. Metafora nawrócenia $i$ „modlitwa filozofa”, tł. P. Mikulska, „Ethos” 19 (2006) nr 3 (75), s. 23-33. 
wiają, że możliwe staje się na gruncie „współczesności-nowoczesności” praktykowanie filozofii jako sztuki życia. Możliwe staje się tym samym konsekwentne i spójne budowanie wizerunku własnego człowieczeństwa. Trudno jednakże odpowiedzieć na pytanie o to, jakie konkretnie filozoficzne modele życia miałyby stać się domeną nowoczesności. Czy należałoby reaktywować klasyczne wzorce, czy może określić zupełnie nowe? A jeśli tak, to jakie? Problematyczność tej kwestii bierze się zapewne $\mathrm{z}$ tego, że powyższe pytania wydają się chyba jednak źle postawione. Ich nietrafność dałoby się porównać do sytuacji, kiedy na przykład samego Sokratesa pytano by o kształt przyszłego „ruchu Sokratycznego”. Absurdalność takiego posunięcia widoczna jest sama przez się. Podobnie też ryzykowne jest prognozowanie, jakie problemy i wyzwania przyniesie współczesność, czy to w szacie nowoczesności, czy ponowoczesności. Trzeba bowiem pamiętać, że filozoficzne modele życia stanowiły konkretną reakcję na konkretne sytuacje. To niejednokrotnie uwarunkowania społeczno-polityczne kształtowały indywidualne życiowe projekty. Stąd też, tak jak niełatwe było prognozowanie, w jakim kierunku wyewoluuje „Sokratejski zaczyn” filozofii, tak trudno jest określić, co - nawet w najbliższej przyszłości - może stać się treścią filozofii jako sztuki życia. Filozoficzne modele życia przybierały postaci tak różne, jak różne były ludzkie potrzeby, problemy i oczekiwania. $Z$ tego powodu motywy poszczególnego sposobu życia odnajdywano w sobie - w trudnościach codzienności, osobistych pragnieniach, ale też w sile ludzkiego ducha, który nieustannie dążył do samoprzekroczenia. Otwarte pozostaje jednak pytanie, czy człowiek współczesny zmienił się aż na tyle, że nie doświadcza potrzeby kształtowania swego życia wedle wzorców cnoty, prawości i szlachetności postępowania? Czy nie doznaje również pragnienia zmierzenia się z tym, co w ludzkiej naturze jest sprawdzianem siły woli i mocy samostanowienia? ${ }^{57}$ Odpowiedzi na te pytania sam musi udzielić sobie każdy, kto próbuje w jakikolwiek sposób zdiagnozować aktualną kondycję człowieka. 


\section{4. „Ponowoczesność” jako kontekst dla współczesnej filozoficznej atopiczności}

Na zakończenie zaryzykuję tezę o możliwości uprawiania filozofii na wzór sztuki życia nawet w „ponowocześnie” rozumianej współczesności. Daje się ona dostrzec wówczas, gdy uświadomimy sobie, że antyczne modele filozoficznego życia często sytuowały się na „peryferiach” ówczesnego życia społeczno-politycznego. Nierzadko okazywały się nawet jego radykalnym zaprzeczeniem, czego znamiennym świadectwem jest

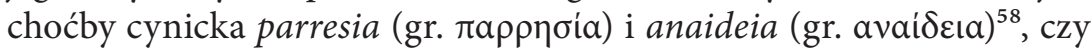
też epikurejski ,indywidualizm”, manifestujący się w wezwaniu do pro-

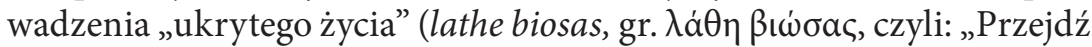
przez życie w cieniu") ${ }^{59}$. Przesłanką do przyjęcia takiej postawy były zapewne znaczące przemiany, które spowodowały upadek polis (państw-

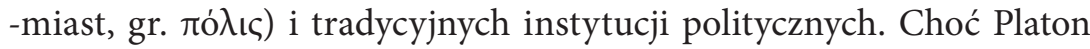
widział człowieka trwale wpisanego w instytucjonalne struktury po-

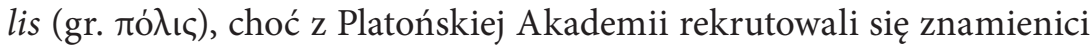
mężowie stanu ${ }^{60}$, to jednak nie szczędził ówczesnemu życiu politycznemu krytycznej oceny. Richard M. Hare twierdzi wręcz, że postawienie właściwej diagnozy niedomaganiom moralno-społecznym, a także znalezienie na nie lekarstwa, stało się zasadniczym impulsem dla całych Sokratejsko-Platońskich wysiłków filozoficznych ${ }^{61}$. Motyw terapeutycznego działania filozofii wróci u epikurejczyków w charakterystycznym dla nich tetrafarmakonie. Zastanawiające jest to, czy owa różnoraka

58 Zob. G. Reale, Historia filozofii starożytnej, t. 3, dz. cyt., s. 48-50.

59 Zob. A. Krokiewicz, Hedonizm Epikura, Warszawa 1961, s. 256. Kwestia stanowiska Epikura wobec życia społecznego jest złożona, gdyż - jak stwierdza Krokiewicz - uznawał on również, że są ludzie jakby stworzeni do pracy społecznej i politycznej, skutkiem czego cierpią i doznają duchowego niepokoju, jeśli jej nie wykonują. Zob. A. Krokiewicz, Hedonizm Epikura, dz. cyt., s. 256.

60 Jak zauważa Maria Maykowska - powołując się na świadectwo Plutarcha - do Platona właśnie ze wszystkich stron przychodzą zapytania, żądania rady i pomocy. Platon wysyłał również swych uczniów do zorganizowania państw: Arystonimosa do Arkadii, Formiona do Elidy, Menedemosa do miasta Pyrra. Zob. M. Maykowska, Wstęp, w: Platon, Listy, przeł. M. Maykowska, Warszawa 1987, s. XIX.

61 Zob. R. M. Hare, Platon, tł. S. Sencerz, Warszawa 1996, s. 27. 
krytyka zastanej rzeczywistości, kontestacja niektórych jej wymiarów nie wpisuje się w paradygmatycznie wręcz wyznaczony przez Sokratesa, filozoficzny aspekt atopiczności. Oznaczałoby to, że filozofia - już z samej swej istoty - skazana jest na ciągłą konfrontację „ze światem”, na nieustanne i krytyczne badanie słuszności jego praw i obyczajów. Tym samym filozof ciągle pozostaje „obcy” współczesnej mu rzeczywistości ${ }^{62}$. Te wybrane przykłady mogą świadczyć o tym, że filozofia jako sztuka życia zawsze sytuowała się w wyraźnej opozycji, albo wobec całego zinstytucjonalizowanego życia społeczno-politycznego, albo też wobec wybranych jego aspektów. Gdy rozbiciu uległy struktury polis

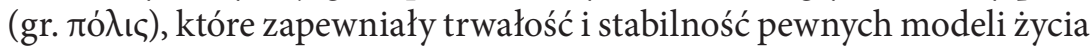
(obywatela, polityka, dowódcy), nie zaginęła - jak się okazuje - potrzeba konsekwentnego ich realizowania ${ }^{63}$. Daje się nawet zaobserwować tutaj pewną prawidłowość. Im bardziej środowisko społeczne i polityczne stawało się „nieprzyjazne”, tym większego znaczenia nabierała wewnętrzna, duchowa przestrzeń ich realizacji ${ }^{64}$. Celem filozoficznych szkół życia staje się od teraz wewnętrzna przemiana - konsekwentne budowanie własnej tożsamości ${ }^{65}$.

Wobec powyższego warto zastanowić się, czy z podobną sytuacją nie mamy do czynienia właśnie w obliczu "ponowoczesnej” współczesności. Czy ona - ze swymi „płynnymi” narracjami - nie jest takim „nieprzyjaznym" środowiskiem? Rozważmy zasadność tej analogii. Skoro arbitralnie znosi możliwość konstruowania własnego obrazu według jednego określonego celu, skoro neguje już samo istnienie tożsamości, a także pełniących rolę wzorca „metanarracji”, to jednocześnie stwarza okazję do koncentracji ludzkiej aktywności przede wszystkim na indywidualnych wysiłkach samookreślenia. Dzieje się więc tutaj dokładnie

62 Zob. L. A. Seneka, O pokoju ducha, XIII, w: L. A. Seneka, Dialogi, dz. cyt., s. 575-576.

${ }^{63} \mathrm{~J}$. Gajda, Gdy rozpadty się ściany świata. Teorie wartości w filozofii hellenistycznej, Wrocław 1995, s. 18.

${ }^{64}$ Przykładem tego mógłby być chociażby egoistyczny rdzeń Epikurejskiej filozofii, który Krokiewicz nazywa „egoizmem dynamicznym”. Zob. A. Krokiewicz, Nauka Epikura, Warszawa 2000, s. 56-57, 227-246.

${ }^{65}$ J. Gajda, Gdy rozpadły się ściany świata..., dz. cyt., s. 43. 
to samo, co w przypadku szkół epoki hellenistycznej. Postulowany przez ponowoczesność powszechny brak struktur potrzebnych do konsekwentnego konstruowania własnej postaci nie sprawi automatycznie, że zniknie również sama jego potrzeba. Szkoły epoki hellenistycznej pokazały, że nawet w momencie pojawienia się niekorzystnych okoliczności, próby samokształtowania intensyfikują się w kierunku wewnętrznej pracy nad sobą. Oznaczałoby to, że „ponowoczesna metanarracja” (w swej paradoksalności mówiąca o braku wielkich narracji) nie jest w stanie przeszkodzić w realizowaniu konkretnego filozoficznego modelu życia. Co więcej, stwarza wręcz okazję do tego, by powstał zupełnie nowy jego model, który będzie uwzględniał i przekraczał właśnie te ponowoczesne ograniczenia. Jeśli więc rozbicie antycznych struktur nie przeszkodziło klasycznym modelom życia filozoficznego w ich rozwoju, a wręcz wpłynęło na ich rozmaitość, to czy nie to samo możemy powiedzieć właśnie o „ponowoczesnej” współczesności? Nawet jeśli ona sama nie widzi we własnej przestrzeni miejsca dla spójnego i konsekwentnego realizowania naczelnego życiowego projektu, to nie znaczy jednocześnie, że zdolna jest taką niemożliwość narzucić tym, którzy znajdą się w jakikolwiek sposób na jej „teoretycznym terytorium”. Może się bowiem okazać, że reakcją na postulowaną "płynną ponowoczesność” będzie właśnie chęć odbudowania spójnej tożsamości.

Reasumując: życie na sposób filozoficzny może spełniać się nie tylko w ramach trwałych „metanarracji” nowoczesności, ale również może być praktykowane jako reakcja i odpowiedź na postulaty ponowoczesności. W ten sposób „aktualność” filozofii jako sztuki życia zyskuje nowe rozumienie. Nie jest to aktualność konkretnych doktryn czy idei, ale aktualność pewnej struktury, schematu i mechanizmu jej funkcjonowania, który widać szczególnie w wymiarze jej atopiczności. Po raz kolejny więc filozofia sytuowałaby się „poza” powszechnie przyjętą akceptacją rzeczywistości - w tym przypadku ponowoczesnej. Stanowiłaby jej krytykę i negację. Tym samym powtarzałaby los swych antycznych poprzedników. Trudno o większe świadectwo jej „aktualności”. 


\section{Bibliografia}

Albert K., O platońskim pojęciu filozofii, przeł. J. Drewnowski, Warszawa 1991.

Albert K., Studia o historii filozofii, przeł. B. Baran, J. Marzęcki, Warszawa 2006.

Albert K., Wprowadzenie do filozoficznej mistyki, przeł. J. Marzęcki, Kęty 2002.

Arystoteles, Etyka nikomachejska, tł. D. Gromska, w: Arystoteles, Dzieła wszystkie, t. 5, Warszawa 1996, s. 7-300.

Arystoteles, Etyka wielka, tł. W. Wróblewski, w: Arystoteles, Dzieła wszystkie, t. 5, Warszawa 1996, s. 301-382.

Arystoteles, Metafizyka, tł. K. Leśniak, w: Arystoteles, Dzieła wszystkie, t. 2, Warszawa 1990, s. 601-857.

Bauman Z., Dwa szkice o moralności ponowoczesnej, Warszawa 1994.

Bauman Z., Etyka ponowoczesna, przeł. J. Bauman, J. Tokarska-Bakir, Warszawa 1996.

Bauman Z., Płynna nowoczesność, przeł. T. Kunz, Kraków 2006.

Bauman Z., Tożsamość. Rozmowy z Benedetto Vecchim, przeł. J. Łaszcz, Gdańsk 2007.

Cicero M. T., Rozmowy tuskulańskie, w: M. T. Cicero, Księgi akademickie. O najwyższym dobru i złu. Paradoksy stoików. Rozmowy tuskulańskie, przeł. W. Kornatowski, J. Śmigaj, Warszawa 1961, s. 475-743.

Czerniak S., Świadomość postmodernistyczna?, w: Postmodernizm a filozofia. Wybór tekstów, red. S. Czerniak, A. Szahaj, Warszawa 1996, s. 13-21.

Dembińska-Siury D., Człowiek odkrywa człowieka. O początkach greckiej refleksji moralnej, Warszawa 1991.

Dembińska-Siury D., Demokrytejska nauka szczęśliwego życia, w: Prawda-język - szczęście. Studia z filozofii starożytnej, red. J. Gajda, A. Orzechowski, D. Dembińska-Siury, Wrocław 1992, s. 108-138.

Diogenes Laertios, Żywoty i poglądy słynnych filozofów, przeł. I. Krońska i in., Warszawa 2004.

Domański J., Erazm i filozofia. Studium o koncepcji filozofii Erazma z Rotterdamu, Wrocław 1973.

Domański J., Metamorfozy pojęcia filozofii, przeł. Z. Mroczkowska, M. Bujko, Warszawa 1996.

Domański J., „Scholastyczne” i „humanistyczne” pojęcie filozofii, Kęty 2005.

Domański J., Tekst jako uobecnienie. Szkic z dziejów myśli o piśmie i książce, Kęty 2002. 
Epiktet, Diatryby, w: Epiktet, Diatryby. Encheiridion z dodaniem Fragmentów oraz Gnomologium epitetowego, przeł. L. Joachimowicz, Warszawa 1961, s. 1-431.

Epikur z Samos, Listy oraz wybór świadectw, opr. K. Pawłowski, Warszawa 2015.

Fearn N., Zenon i żółw. Jak myśla filozofowie, przeł. M. Pawlikowska, Warszawa 2007.

Gajda J., Gdy rozpadły się ściany świata. Teorie wartości w filozofii hellenistycznej, Wrocław 1995.

Gajda J., Teorie wartości w filozofii przedplatońskiej, Wrocław 1992.

Gajda-Krynicka J., Filozofia przedplatońska, Warszawa 2007.

Giddens A., Nowoczesność i tożsamość. „Ja” i społeczeństwo w epoce późnej nowoczesności, tł. A. Szulżycka, Warszawa 2010.

Gigon O., Główne problemy filozofii starożytnej, przeł. P. Domański, Warszawa 1996.

Gwiazdecka J., Etyka Platona. O formie platońskiej refleksji moralnej, Kęty 2003.

Hadot P., Czym jest filozofia starożytna?, przeł. P. Domański, Warszawa 2000.

Hadot P., Filozofia jako ćwiczenie duchowe, przeł. P. Domański, Warszawa 2003.

Hadot P., Twierdza wewnętrzna: wprowadzenie do „Rozmyślań” Marka Aureliusza, przeł. P. Domański, Kęty 2004.

Hare R. M., Platon, tł. S. Sencerz, Warszawa 1996.

Jaeger W., Paideia. Formowanie człowieka greckiego, przeł. M. Plezia, H. Bednarek, Warszawa 2001.

Jaeger W., Teologia wczesnych filozofów greckich, przeł. J. Wocial, Kraków 2007.

Kowalczyk S., Idee filozoficzne postmodernizmu, Radom 2004.

Kowalczyk S., Pytanie o prawdę w ponowoczesności, w: Nowoczesność/ponowoczesność. Fenomen i wyzwanie, red. J. Wojciechowski, Warszawa 2009, s. 43-53.

Krąpiec M. A., Czym jest filozofia klasyczna?, w: W kręgu filozofii klasycznej, red. B. Dembiński, Katowice 2000, s. 9-23.

Krąpiec M. A., Filozofia co wyjaśnia?, Lublin 1998.

Krokiewicz A., Arystoteles, Pirron i Plotyn, Warszawa 1974.

Krokiewicz A., Hedonizm Epikura, Warszawa 1961.

Krokiewicz A., Nauka Epikura, Warszawa 2000.

Krokiewicz A., Zarys filozofii greckiej, Warszawa 2000.

Ksenofont, Wspomnienia o Sokratesie, w: Ksenofont, Pisma sokratyczne, przeł. L. Joachimowicz, Warszawa 1967, s. 15-237.

Kunce A., Tożsamość i postmodernizm, Warszawa 2003.

Kwintylian M. F., Kształcenie mówcy, tł. M. Brożek, Warszawa 2002. 
Lyotard J.-F., Kondycja ponowoczesna. Raport o stanie wiedzy, przeł. M. Kowalska, J. Migasiński, Warszawa 1997.

Marek Aureliusz, Rozmyślania (do siebie samego), przeł. K. Łapiński, Warszawa 2011.

Maykowska M., Wstęp, w: Platon, Listy, przeł. M. Maykowska, Warszawa 1987, s. VII-LIII. Narecki K., LOGOS we wczesnej myśli greckiej, Lublin 1999.

Paczkowski P., Filozoficzne modele życia w klasycznym antyku (IV w. p.n.e.), Rzeszów 2005. Paczkowski P., Jedność filozofii Platona, Rzeszów 1998.

Paczkowski P., Rola Platona i ruchu sokratycznego w kształtowaniu antycznego modelu filozoficznego życia, w: Filozofia jako sztuka życia. Teorie, modele i wzorce dla doradztwa filozoficznego, red. A. Woszczyk, D. Olesiński, Katowice 2013.

Platon, Państwo, w: Platon, Państwo. Prawa (VII ksiag), przeł. W. Witwicki, Kęty 2001, s. $11-338$.

Platon, Uczta, przeł. W. Witwicki, w: Platon, Dialogi, t. 2, Kęty 2005, s. 3-90.

Reale G., Dwa przesłania Platona dla ludzi wszystkich czasów. Metafora nawrócenia $i$ „modlitwa filozofa”, tł. P. Mikulska, „Ethos” 19 (2006) nr 3 (75), s. 23-33.

Reale G., Historia filozofii starożytnej, t. 3: Systemy epoki hellenistycznej, przeł. E. I. Zieliński, Lublin 2004.

Reale G., Pojęcie człowieka, troski o duszę i duchowego Erosa jako przesłanie myśli antycznej dla człowieka współczesnego, tł. P. Mikulska, „Ethos” 13 (2000) nr 1-2 (49-50), s. $32-45$.

Reale G., Zło nękające współczesnego człowieka i lekarstwo, jakie można na nie znaleźć w myśli antycznej, tł. E. I. Zieliński OFMConv, „Ethos” 14 (2001) nr 4 (56), s. 15-39.

Sekstus Empiryk, Przeciw etykom, w: Sekstus Empiryk, Przeciw fizykom. Przeciw etykom (Adversus mathematicos IX-XI), przeł. Z. Nerczuk, Kęty 2010, s. 165-235.

Sekstus Empiryk, Zarysów Pirrońskich księga pierwsza, druga i trzecia, przeł. A. Krokiewicz, Kraków 1931.

Seneka L. A., Listy moralne do Lucyliusza, przeł. W. Kornatowski, Warszawa 1998.

Seneka L. A., O niezłomności mędrca, w: L. A. Seneka, Dialogi, przeł. L. Joachimowicz, Warszawa 1998, s. 480-513.

Seneka L. A., O pokoju ducha, w: L. A. Seneka, Dialogi, przeł. L. Joachimowicz, Warszawa 1998, s. 540-587.

Seneka L. A., O życiu szczęśliwym, w: L. A. Seneka, Dialogi, przeł. L. Joachimowicz, Warszawa 1998, s. 157-202.

Seńko W., Jak rozumieć filozofię średniowieczną, Kęty 2001. 
Skrzypek-Faluszczak J., Ocalenie od zła w filozofii Platona, Kraków 2010.

Snell B., Odkrycie ducha. Studia o greckich korzeniach europejskiego myślenia, przeł.

A. Onysymow, Warszawa 2009.

Szlezák T. A., O nowej interpretacji platońskich dialogów, przeł. P. Domański, Kęty 2005. Swieżawski S., Dzieje europejskiej filozofii klasycznej, Warszawa-Wrocław 2000.

Swieżawski S., O filozofii wieczystej, w: S. Swieżawski, Prawda i tajemnica. Pisma filozoficzne, Warszawa 2007, s. 33-39.

Taylor Ch., Źródła podmiotowości. Narodziny tożsamości nowoczesnej, przeł. A. Lipszyc,

Warszawa 2012.

\section{Abstrakt \\ Antyczna tradycja filozoficznych sposobów życia jako wzorzec dla współczesności}

W niniejszym artykule prezentuję filozofię rozumianą jako sposób życia i pytam o jej aktualność lub dezaktualizację we „współczesności”. Na początku definiuję to, czym jest filozoficzny sposób życia i czym on się charakteryzuje. Następnie wskazuję na dwa aspekty ludzkiej „natury”, które warunkują realizację tego sposobu życia: konieczność istnienia spójnej tożsamości i całościowego egzystencjalnego projektu (celu).

W punkcie drugim ukazuję „współczesność” w jej napięciu między nowoczesnością a „ponowoczesnością”. Nawiązuję tutaj do charakterystyki tej ostatniej, sformułowanej przez Zygmunta Baumana. Natomiast w punkcie trzecim pytam o możliwość funkcjonowania filozofii, jako sposobu życia, w tak zdefiniowanej „współczesności”.

Wskazuję, że wyklucza ona takie funkcjonowanie ze względu na postulowaną „płynną tożsamość", a precyzyjniej mówiąc - na brak tej tożsamości i niemożliwość jej spójnego skonstruowania według przyjętego określonego wzorca. $Z$ drugiej jednak strony zauważam, że - paradoksalnie - „ponowoczesność” może być przestrzenią realizacji filozoficznej egzystencji w momencie, gdy uznamy, że negacja, poczucie obcości i stawianie się w krytycznej opozycji wobec ustalonego porządku były charakterystycznymi cechami antycznego filozofowania, którego paradygmat swą atopicznością wyznaczył Sokrates. Zatem filozoficzny sposób życia możliwy jest do realizacji nawet w tej epoce, która sama ideowo zaprzecza takiej możliwości. 


\section{Słowa kluczowe}

filozofia, sposób życia, psyche, troska o duszę, tożsamość, nowoczesność, ponowoczesność, wzorce osobowe

\section{Abstract \\ The Ancient Tradition of Philosophical Ways of Life as a Model for Contemporaneity}

In this article, I present philosophy understood as a way of life and ask about its relevance or its loss of timeliness in 'contemporaneity.' At the beginning I define what is the philosophical way of life and what are its characteristics. Then, I point to two aspects of human 'nature,' which condition the achievement of this way of life: the need for a coherent identity and a comprehensive existential project (goal).

The second point shows the 'contemporaneity' in its tension between modernity and the 'post-contemporaneity.' I refer here to the characteristics of the latter, formulated by Zygmunt Bauman. However, in the third point I ask about the possibility of the functioning of philosophy as a way of life, in such defined 'contemporaneity'.

I indicate that it excludes such functioning due to the postulated 'fluid identity' and to be precise, to a lack of identity and the impossibility of its coherent construct according to an adopted, specific pattern. On the other hand, I note that - paradoxically - 'postmodernism' can be a space for realization of a philosophical existence at a time when we assume that negation, a sense of alienation and putting ourselves in a critical opposition to the established order, was a characteristic of ancient philosophical thought, the paradigm of which, with its atopic thinking, was appointed by Socrates. Thus, the philosophical way of life is possible to realize even in this era, which itself ideologically denies this possibility.

\section{Keywords}

philosophy, way of life, psyche, care for the soul, identity, modernity, postmodernity, role models 